\title{
Aplikasi Media Pembelajaran Pengenalan Kosakata Harian Bahasa Arab Dengan Metode Multimedia Development Life Cycle (MDLC)
}

\author{
Ari Nurul Alfian ${ }^{1, *}$ \\ ${ }^{1}$ Manajemen Informatika; Universitas Bina Insani; JI.Siliwangi No.6 Rawa Panjang Bekasi- \\ Bekasi Timur 17114 Indonesia, Telp. (021)824 36886 / (021)824 36 996. Fax. (021)824 009 24; \\ e-mail: arin@binainsani.ac.id \\ * Korespondensi:e-mail: arin@binainsani.ac.id
}

Diterima: 17 Desember 2020; Review: 22 Desember 2020; Disetujui: 29 Desember 2020

Cara sitasi: Alfian AN. 2020. Aplikasi Media Pembelajaran Pengenalan Kosakata Harian Bahasa Arab Dengan Metode Multimedia Development Life Cycle (MDLC). Vol.5 (1) : 95-104.

\begin{abstract}
Abstrak: Salah satu solusi untuk mengatasi permasalahan dalam pembelajaran adalah dengan pemanfaatan media pembelajaran. Media pembelajaran merupakan sebuah alat bantu komunikasi antara guru dan siswa untuk mempermudah penyampaian suatu informasi dalam sebuah pembelajaran. Penelitian yang telah dilakukan pada pengembangan media pembelajaran Adobe Flash CS6 mengenai kosakata harian Bahasa Arab. Tujuan dari penelitian ini adalah untuk merancang dan mengembangkan media pembelajaran dan uji penerimaan (user acceptance test). Aplikasi yang dikembangkan memiliki fitur yang berguna untuk meningkatkan kemampuan siswa mempelajari dan menghapal kosakata serta pengucapan yang benar. Program aplikasi telah diuji pada jenis perangkat komputer yang berbeda serta diuji kepada guru dan siswa secara sampling. Hasil penelitian menunjukkan bahwa aplikasi media pembelajaran kosakata Bahasa Arab dapat bekerja dengan baik dan responden, secara umum, menyatakan bahwa program aplikasi memuaskan untuk digunakan dalam mempelajari kosakata Harian Bahasa Arab untuk siswa.
\end{abstract}

Kata kunci: adobe flash CS6, kosakata bahasa arab, mufrodat, media pembelajaran, multimedia, user acceptance test.

Abstract: One solution to solving problems in learning is the use of learning media. Learning media is a communication tool between teachers and students to facilitate the delivery of information in a lesson. Research that has been done on the development of Adobe Flash CS6 learning media regarding daily Arabic vocabulary. The purpose of this study is to design and develop instructional media and a user acceptance test. The application developed has useful features to improve students' ability to learn and memorize vocabulary and correct pronunciation. The application program has been tested on different types of computer equipment and tested on teachers and students by sampling. The results showed that the application of Arabic vocabulary learning media could work well and respondents, in general, stated that the application program was satisfactory to be used in learning Arabic daily vocabulary for students.

Keywords: adobe flash CS6, mufrodat, learning media, multimedia, user acceptance test, vocabulary arabic

\section{Pendahuluan}

Berkembangnya teknologi disertai dengan pertumbuhan di bidang ilmu pengetahuan membuat teknologi diera modernisasi zaman sekarang semakin canggih, sehingga membuat manusia semakin sadar bahwa Pendidikan di era sekarang merupakan hal yang sangat penting. Dengan adanya Pendidikan, manusia dapat membekali dirinya dengan segudang ilmu pengetahuan guna meningkatkan kualitas diri, serta dapat mengikuti perkembangan zaman yang semakin hari semakin maju. Pendidikan merupakan usaha sadar dan terencana untuk mewujudkan proses kegiatan belajar mengajar bagi para siswa sebagai bagian dari 
pengembangan potensi yang dimiliki siswa agar mempunyai kekuatan dibidang intelektual dan spiritual untuk dimamfaatkan dimasa mendatang [1].

Tantangan era globalisasi sekarang semakin ketat dimana mengharuskan kita agar dapat bersaing dengan negara-negara lain. Salahsatunya adalah dengan kemampuan kita berkomunikasi dan bernegosiasi dengan negara lain. Hal tersebut tentu saja kita diharuskan mempunyai kemampuan Bahasa internasional. Salah satu bahasa Internasional yang yang diakui oleh PBB adalah bahasa Arab. Bahasa Arab merupakan bahasa resmi untuk beberapa negara yang berada pada kawasan Asia Barat dan Afrika Utara. Bahasa Arab juga menjadi bahasa pendidikan, ilmu pengetahuan, diplomasi, transaksi sosial dan ekonomi, dan budaya[2].

Bahasa Arab di Indonesia menjadi salah satu mata pelajaran wajib pada satuan pendidikan dibawah naungan Kemenag, mulai dari tingkatan dasar hingga perguruan tinggi. Seluruh satuan pendidikan tersebut mengajar Bahasa Arab sebagai salah satu bahasa Asing yang diajarkan selain bahasa Inggris. Meskipun dalam pembelajaran mengalami berabagi macam masalah baik dalam pelaksanaan atau penerapannya, rasa kebosanan para pembelajar dalam belajar bahasa serta kurangnya penguasaan dan inovasi pengajar dalam proses pembelajaran dikelas menjadi salah satu masalah yang dihadapi. Baik terkait dengan materi, strategi, metode, teknik, evaluasi ataupun media pembelajarannya. Bahasa mempunyai arti sebagai suatu wadah karakter suara yang digunakan oleh setiap manusia untuk berinteraksi, berkomunikasi,ataupun mengenali diri[3]. Bahasa Arab merupakan suatu bunyi yang digunakan oleh masyarakat arab untuk berkorespondensi dan berkomunikasi[4].

Salah satu unsur bahasa asing yang sangat penting untuk dikuasai oleh pembelajar adalah kosakata. Penguasaan kosakata Arab (mufrodat) menjadi salah satu kunci dalam penguasaan bahasa Arab. Dalam bahasa Arab terdapat kelemahan menguasainya salah satunya adalah karena minimnya kosakata yang dimiliki sehingga pembelajar merasa bahwa belajar bahasa sangatlah sulit dan membosankan. Padahal kemampuan seseorang untuk memahami empat kemahiran berbahasa tergantung pada penguasaan kosakata yang dimiliki dan sangat berperan penting[5]. Kosakata adalah hal penting yang dapat digunakan sebagai titik dasar dalam kemajuan dan kemahiran seseorang menguasai ilmu Bahasa Arab[6].

Salah satu solusi untuk mengatasi permasalahan dalam pembelajaran adalah dengan pemanfaatan media pembelajaran. Media pembelajaran merupakan sebuah alat bantu komunikasi antara guru dan siswa untuk mempermudah penyampaian suatu informasi dalam sebuah pembelajaran. Pesan pembelajaran yang dibawakan oleh media tersebut adalah hal yang terpenting bukan hanya medianya saja[7]. Adanya media pembelajaran diharapkan dapat meningkatkan motivasi dan minat siswa dalam belajar, membantu meningkatkan pemahaman, menyajikan data dengan cara yang lebih menarik dan memahamkan, serta menambah semangat untuk belajar.

Seiring dengan kemajuan teknologi informasi, sarana pembelajaran dapat dilakukan menggunakan perangkat multimedia baik berupa personal computer (PC), atau laptop. Aplikasi multimedia yang difungsikan sebagai pendamping buku teks dalam pembelajaran ternyata mampu meningkatkan minat siswa yang pada akhirnya mampu meningkatkan pemahaman siswa, apabila dibandingkan dengan hanya menggunakan buku teks saja contohnya adalah program aplikasi pembelajaran interaktif pengenalan profesi berbasis multimedia menggunakan Adobe Flash CS6 [8].

Media adalah sebuah kata yang berasal dari bahasa latin yakni medius yang secara harfiah bermakna "tengah", "pengantar", atau "perantara". Sedangkan Media dalam Bahasa Arab bermakna "pengantar atau perantara pesan dari pengirim kepada yang menerima pesan [9]. Salah satu sarana yang dapat digunakan sebagai perantara yang berguna untuk meningkatkan efektifitas dan efisiensi dalam mencapai tujuan adalah Media [10]. Kegunaan media pembelajaran diantaranya yaitu pesan yang bersifat verbalistis menjadi lebih jelas penyajiannya jika disampaikan melalui media pembelajaran, belajar menjadi tidak terbatas, mengatasi sikap pasif anak didik, sebagai perangsang belajar, menyamakan pengalaman dan menimbulkan persepsi yang sama [11].

Penggunaan model media pembelajaran yang memerlukan perangkat keras (hardware) dan perangkat lunak (software) untuk saat ini menjadi sesuatu yang penting untuk diberikan [12]. Salah satu perangkat lunak yang sangat mendukung dalam penerapannya sebagai media pembelajaran interaktif ini adalah Adobe Flash CS6 yang memiliki seluruh elemen multimedia agar nantinya dapat digunakan secara maksimal untuk meningkatkan proses pembelajaran serta prestasi siswa. Sebuah program untuk membuat animasi, media pembuat aplikasi, game, desain 
web, dan media presentasi maupun pembelajaran interaktif yang mampu mengolah teks serta objek dengan efek dua hingga tiga dimensi sehingga hasilnya lebih menarik menggunakan Adobe Flash Professional CS6[13].

Program aplikasi multimedia pembelajaran kosakata harian Bahasa Arab masih belum banyak mendapatkan perhatian dari peneliti, sehingga peneliti berupaya untuk membuat media pembelajaran kosakata harian Bahasa Arab berbasis Adobe Flash CS6 untuk memudahkan pemahaman siswa.

Program aplikasi multimedia kosakata harian Bahasa Arab mengenalkan tentang kosakata yang terdapat di Rumah, kosakata Bilangan 1-10 dan kosakata beberapa Hewan serta kuis sebagai evaluasi pemahaman siswa.

\section{Metode Penelitian}

Metode Penelitain yang digunakan pada penelitian ini adlaah Multimedia Development Life Cycle (MDLC). Pada penelitian yang diusulkan ini akan mempunyai beberapa tahap yaitu konsep, desain, pengumulan materi, pembuatan program aplikasi, pengujian program aplikasi, dan pengujian penerimaan pengguna (user acceptance test/UAT) yaitu survey penggunaan program aplikasi oleh calon pengguna yang dipilih secara acak baik responden umum, orang tua, murid sekolah dasar maupun guru (Tabel 1 dan 2). Data statistik hasil penyebaran angket atau kuesioner kepada calon pengguna dipilih secara acak disebar melalui google formulir. Data yang ingin diketahui dari calon pengguna secara garis besar meliputi apakah program aplikasi yang dibuat sudah menarik, apakah program aplikasi yang dibuat sudah user friendly, dan apakah program aplikasi yang dibuat dapat digunakan membantu proses pembelajaran.

$y=\left(\frac{p}{q}\right) * 100 \%$

$y=$ nilai prosentase

$\mathrm{p}=$ banyaknya jawaban siswa di tiap soal

$\mathrm{q}=$ jumlah siswa

Tabel 1 Tabel Pengujian kepada Siswa

\begin{tabular}{|c|c|c|}
\hline No. & Poin-poin yang diteliti & Skala Penilaian \\
\hline 1 & $\begin{array}{l}\text { Apakah Ananda sebelumnya pernah } \\
\text { menggunakan aplikasi seperti ini? }\end{array}$ & $\mathrm{S}=$ Sudah, $\mathrm{B}=$ Belum, \\
\hline 2 & Apakah tampilan aplikasi ini bagus? & $\begin{array}{l}\mathrm{SBg}=\text { Sangat Bagus, } \mathrm{Bg}=\mathrm{Bagus}, \mathrm{CBg}=\text { Cukup Bagus, } \\
\mathrm{J}=\mathrm{J} \text { elek. } \mathrm{SJ}=\text { Sangat Jelek. }\end{array}$ \\
\hline 3 & $\begin{array}{l}\text { Apakah pengoperasian aplikasi Media } \\
\text { pembelajaran kosakata harian Bahasa Arab } \\
\text { pada aplikasi ini mudah? }\end{array}$ & $\begin{array}{l}\text { SM=Sangat Mudah, } M=\text { Mudah, } C M=\text { Cukup Mudah, } \\
\text { TM=Tidak Mudah, STM=Sangat Tidak Mudah }\end{array}$ \\
\hline 4 & Apakah proses menjalankan aplikasi ini cepat? & $\begin{array}{l}\mathrm{SCp}=\text { Sangat Cepat, } \mathrm{Cp}=\text { Cepat, } C C p=\text { Cukup Cepat, } \\
\mathrm{L}=\mathrm{Lambat}, \mathrm{SL}=\text { Sangat Lambat. }\end{array}$ \\
\hline 5 & $\begin{array}{l}\text { Apakah fitur aplikasi Media pembelajaran } \\
\text { kosakata harian Bahasa Arab ini bermanfaat? }\end{array}$ & $\begin{array}{l}\mathrm{SBm}=\text { Sangat Bermanfaat, } \mathrm{Bm}=\text { Bermanfaat, } \mathrm{CBm}=\text { Cukup } \\
\text { Bermanfaat, TBm=Tidak Bermanfaat, STBm=Sangat } \\
\text { Tidak Bermanfaat. }\end{array}$ \\
\hline 6 & $\begin{array}{l}\text { Apakah tingkat error aplikasi Media } \\
\text { pembelajaran kosakata harian Bahasa Arab ini } \\
\text { tinggi? }\end{array}$ & $\begin{array}{l}\text { SR=Sangat Rendah, } R=\text { Rendah, } C T=\text { Cukup Tinggi, } \\
\mathrm{T}=\text { Tinggi, ST=Sangat Tinggi. }\end{array}$ \\
\hline 7 & $\begin{array}{l}\text { Apakah keseluruhan aplikasi Media } \\
\text { pembelajaran kosakata harian Bahasa Arab ini } \\
\text { bagus? }\end{array}$ & $\begin{array}{l}\mathrm{SBg}=\text { Sangat Bagus, } \mathrm{Bg}=\mathrm{Bagus}, \mathrm{CBg}=\text { Cukup Bagus, } \\
\mathrm{J}=\mathrm{J} \text { elek, } \mathrm{SJ}=\text { Sangat Jelek. }\end{array}$ \\
\hline 8 & $\begin{array}{l}\text { Apakah aplikasi ini cocok untuk media belajar } \\
\text { mandiri/tanpa guru? }\end{array}$ & $\begin{array}{l}\mathrm{SC}=\text { Sangat Cocok, } \mathrm{C}=\text { Cocok, } \mathrm{CC}=\text { Cukup Cocok, } \\
\mathrm{TC}=\text { Tidak Cocok }, \mathrm{STC}=\text { Sangat Tidak Cocok. }\end{array}$ \\
\hline
\end{tabular}

Sumber: Penelitian (2020)

$y=\left(\frac{p}{q}\right) * 100 \%$

$y=$ nilai prosentase

$\mathrm{p}=$ banyaknya jawaban siswa di tiap soal

$\mathrm{q}=$ jumlah guru

Pada tabel 2 adalah poin-poin pertanyaan yang ditujukan kepada guru dan untuk rumusnya dijelaskan sebagai berikut: 
Tabel 2 Tabel Pengujian kepada Guru

\begin{tabular}{|c|c|c|}
\hline No. & Poin-poin yang diteliti & Skala Penilaian \\
\hline 1 & $\begin{array}{l}\text { Apakah Bapak/lbu Guru sebelumnya pernah } \\
\text { menggunakan aplikasi seperti ini? }\end{array}$ & $\mathrm{S}=$ Sudah, $\mathrm{B}=$ Belum. \\
\hline 2 & Apakah tampilan aplikasi ini bagus? & $\begin{array}{l}\mathrm{SBg}=\text { Sangat Bagus, } \mathrm{Bg}=\text { Bagus, } \mathrm{CBg}=\text { Cukup Bagus, } \\
\text { TBg=Tidak Bagus, STBg=Sangat Tidak Bagus. }\end{array}$ \\
\hline 3 & Apakah pengoperasian aplikasi ini mudah? & $\begin{array}{l}\text { SM=Sangat Mudah, } M=\text { Mudah, } C M=\text { Cukup Mudah, } \\
\text { TM=Tidak Mudah, STM=Sangat Tidak Mudah. }\end{array}$ \\
\hline 4 & Apakah kecepatan loading aplikasi ini cepat? & $\begin{array}{l}\text { SC } p=\text { Sangat Cepat, } C p=\text { Cepat, } C C p=\text { Cukup Cepat, } \\
\text { TCp }=\text { Tidak Cepat, STC } p=\text { Sangat Tidak Cepat }\end{array}$ \\
\hline 5 & $\begin{array}{l}\text { Apakah fitur Media pembelajaran kosakata } \\
\text { harian Bahasa Arab ini bermanfaat? }\end{array}$ & $\begin{array}{l}\text { SBm=Sangat Bermanfaat, Bm=Bermanfaat, } \mathrm{CBm}=\text { Cukup } \\
\text { Bermanfaat, TBm=Tidak Bermanfaat, STBm=Sangat } \\
\text { Tidak Bermanfaat. }\end{array}$ \\
\hline 6 & $\begin{array}{l}\text { Apakah soal-soal kuis sudah mencakup } \\
\text { evaluasi keseluruhan pembelajaran? }\end{array}$ & $\begin{array}{l}\mathrm{SM}=\text { Sangat Mencakup, } \mathrm{M}=\text { Mencakup, } \mathrm{CM}=\text { Cukup } \\
\text { Mencakup, TM=Tidak Mencakup, STM=Sangat Tidak } \\
\text { Mencakup. }\end{array}$ \\
\hline 7 & $\begin{array}{l}\text { Apakah aplikasi pembelajaran kosakata harian } \\
\text { Bahasa Arab ini sudah lengkap? }\end{array}$ & $\begin{array}{l}\text { SLk=Sangat Lengkap, Lk=Lengkap, CLk=Cukup Lengkap, } \\
\text { TLk=Tidak Lengkap, STLk=Sangat Tidak Lengkap. }\end{array}$ \\
\hline 8 & $\begin{array}{l}\text { Apakah aplikasi ini cocok untuk media belajar } \\
\text { mandiri/tanpa guru? } \\
\text { Apakah Media pembelajaran kosakata harian }\end{array}$ & $\begin{array}{l}\mathrm{SC}=\text { Sangat Cocok, } \mathrm{C}=\text { Cocok, } \mathrm{CC}=\text { Cukup Cocok, } \\
\mathrm{TC}=\text { Tidak Cocok, } \mathrm{STC}=\text { Sangat Tidak Cocok. } \\
\mathrm{SMb}=\text { Sangat Membantu, Mb=Membantu, } \mathrm{CMb}=\text { Cukup }\end{array}$ \\
\hline 9 & $\begin{array}{l}\text { Bahasa Arab ini membantu dalam proses } \\
\text { belajar mengajar? }\end{array}$ & $\begin{array}{l}\text { Membantu, TMb=Tidak Membantu, STMb=Sangat Tidak } \\
\text { Membantu. }\end{array}$ \\
\hline
\end{tabular}

Sumber: Penelitian (2020)

Peralatan yang digunakan untuk merancang dan mengembangkan program aplikasi dan pengujian fungsi perangkat lunak Macromedia Flash adalah satu unit laptop dengan prosessor AMD E1-6010 APU with AMD Radeon R2 Graphics, RAM 2.00 GB, dengan sistem operasi MS Windows 7 64-bit.

Proses pembuatan aplikasi pembelajaran kosakata harian Bahasa Arab menggunakan Adobe Flash Professional CS6 ini terlebih dahulu dibuat rancangan desain tampilannya, diantaranya rancangan scene intro, scene menu utama, scene materi, scene kuis, dan scene pengembang. Pada halaman mulai berisi judul aplikasi dan tombol mulai belajar sehingga langsung menuju scene menu utama yang menyediakan pilihan menu materi, kuis, dan pengembang, serta pilihan keluar. Pembuatan desain tampilan selain menggunakan Adobe Flash Professional CS6 juga menggunakan perangkat lunak grafis lain yaitu Adobe Illustrator.

\section{Hasil dan Pembahasan Tampilan Awal Program}

Tampilan awal program diakses melalui sebuah ikon aplikasi (.exe) sebagai jalan pintas untuk menjalankannya. Sehingga akan muncul tampilan awal program atau scene intro. Tampilan scene intro muncul ketika pengguna menjalankan aplikasi (.exe) pembelajaran Kosakata Harian Bahasa Arab yang akan langsung menuju scene salam yang dapat dilihat pada gambar 1.

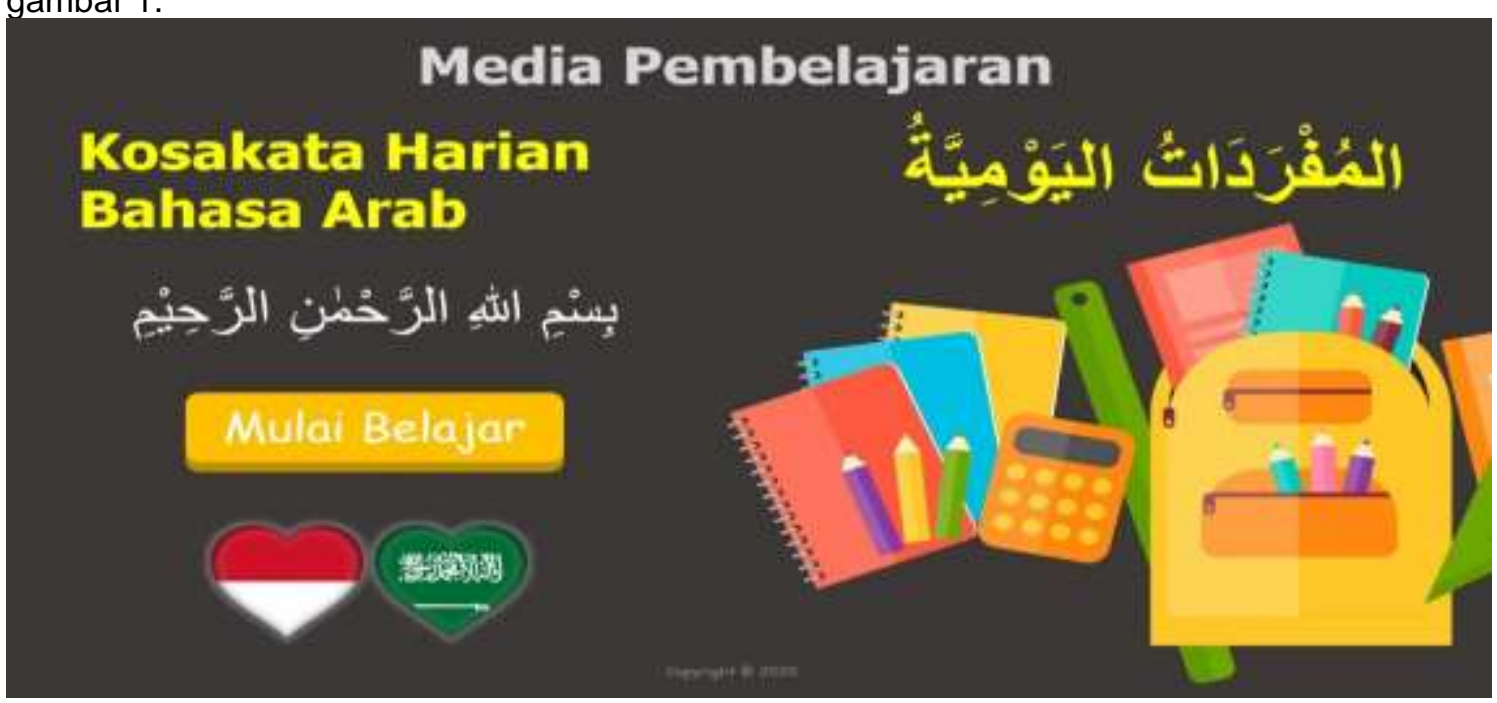

Sumber: Hasil Penelitian (2020)

Gambar 1. Tampilan Mulai Belajar 
Tampilan scene Mulai Belajar muncul berupa animasi tombol "Mulai Belajar" yang menggunakan animasi scale. Setelah scene Mulai Belajar ini tampil maka akan langsung menuju halaman utama atau scene menu utama yang memunculkan beberapa tombol seperti tombol materi, tombol kuis, tombol pengembang dan tombol musik serta tombol untuk menutup aplikasi (close application). dapat dilihat pada gambar 2.

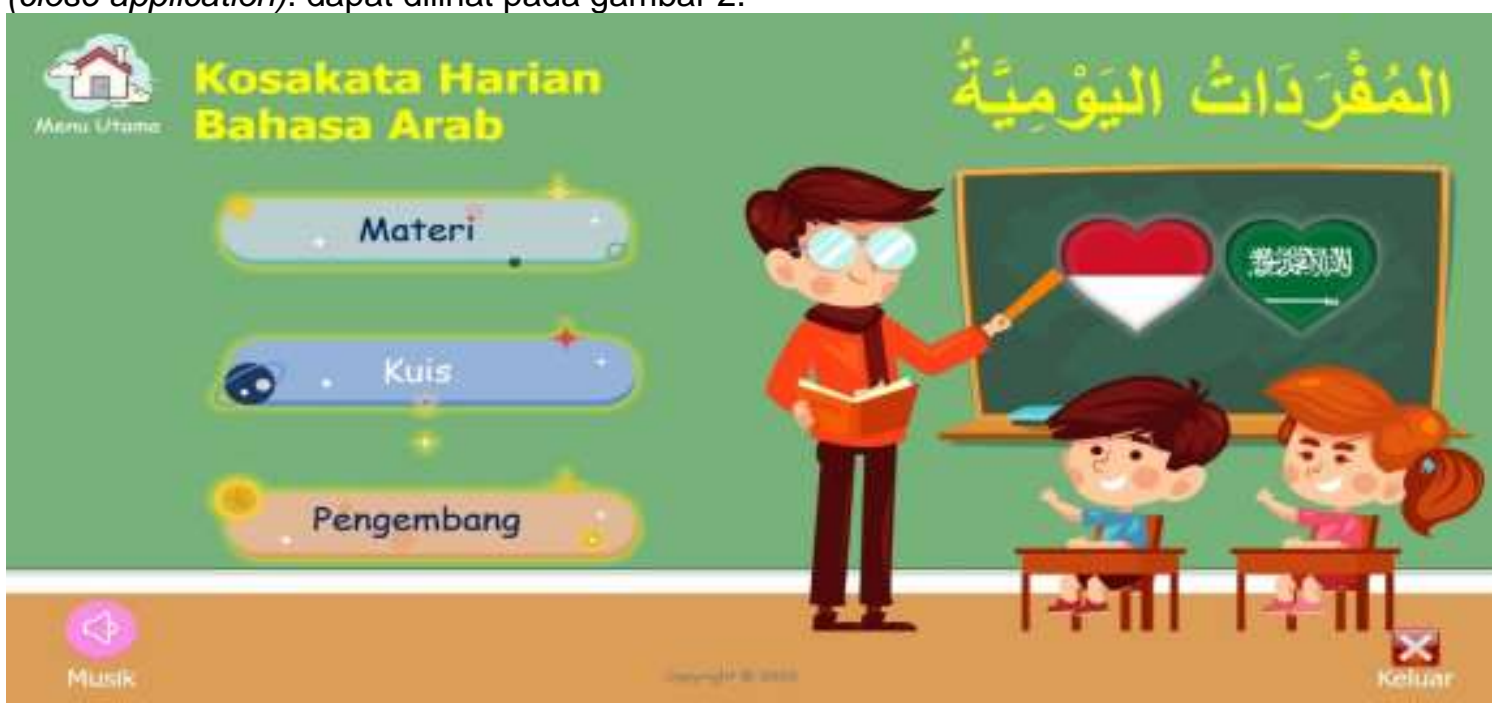

Sumber: Hasil Penelitian (2020)

Gambar 2. Tampilan Menu Utama

Tampilan menu awal dibuat dengan warna font serta icon dan animasi yang menarik untuk membuat tampilan aplikasi lebih menarik.

\section{Tampilan Pilihan Materi Kosakata Bahasa Arab}

Tampilan materi tentang Kosakata Harian Bahasa Arab terdapat pada tombol materi pertama pada gambar 3 dengan tulisan "Materi" yang ketika dipilih akan menuju scene pilihan materi. Scene Materi Kosakata Harian Bahasa Arab dapat dilihat pada gambar 4.

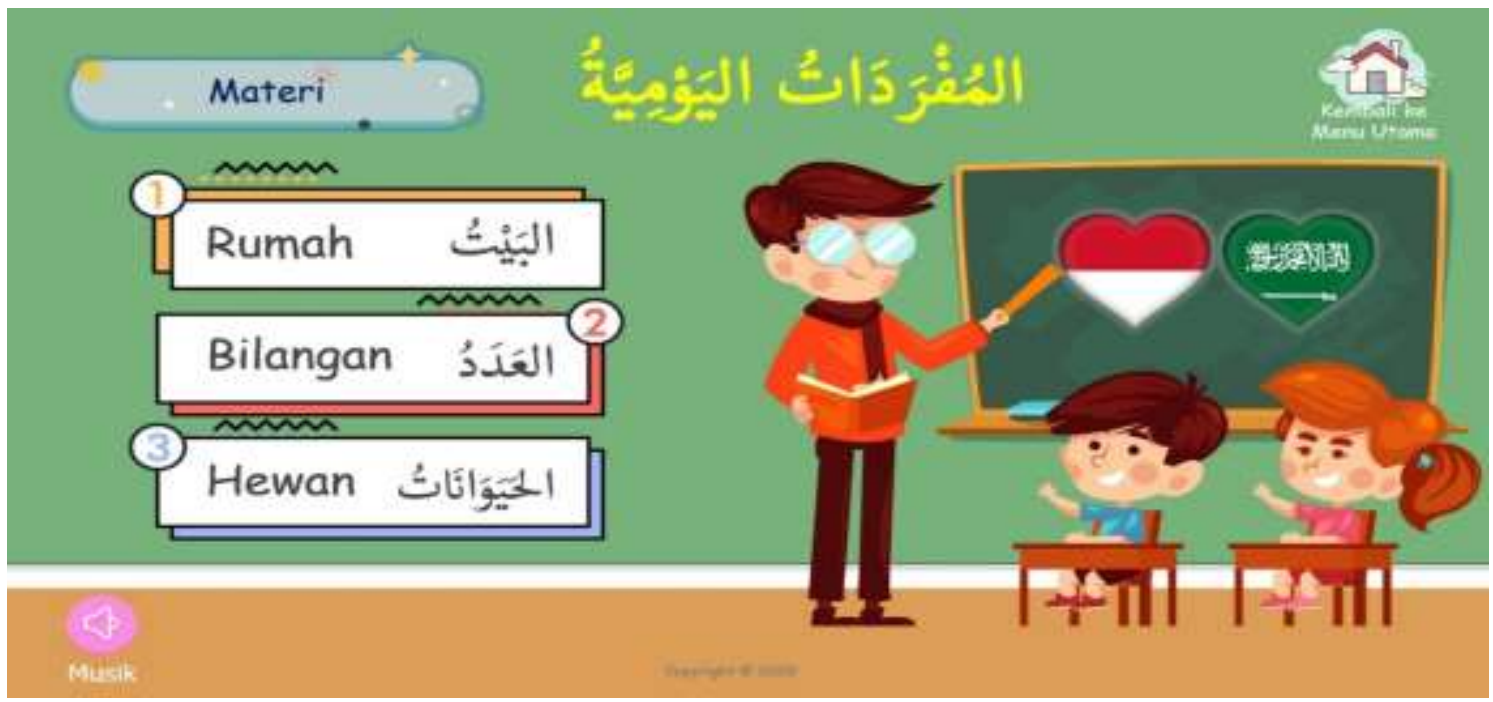

Sumber: Hasil Penelitian (2020)

Gambar 3. Tampilan Scene Materi Kosakata Harian Bahasa Arab

Pada tampilan pilihan materi Kosakata Harian Bahasa Arab, meliputi pilihan pertama adalah kosakata yang terdapat di Rumah, pilihan kedua adalah kosakata Bilangan 1-10 dan yang ketiga adalah kosakata beberapa Hewan, terdapat pula menu kembali yang dinavigasikan 
menggunakan tombol "Kembali ke Menu Utama" untuk kembali ke menu utama dan terdapat pula tombol untuk menutup aplikasi (close application).

Setelah mengetahui pilihan menu apa saja yang dapat dilihat dan dipelajari, maka pengguna dapat memilih materi pertama mengenai kosakata harian Bahasa Arab yang terdapat di Rumah. Tampilan mengenai kosakata harian Bahasa Arab yang terdapat di Rumah pengguna dapat memilih tombol "Rumah", dapat dilihat pada gambar 4.

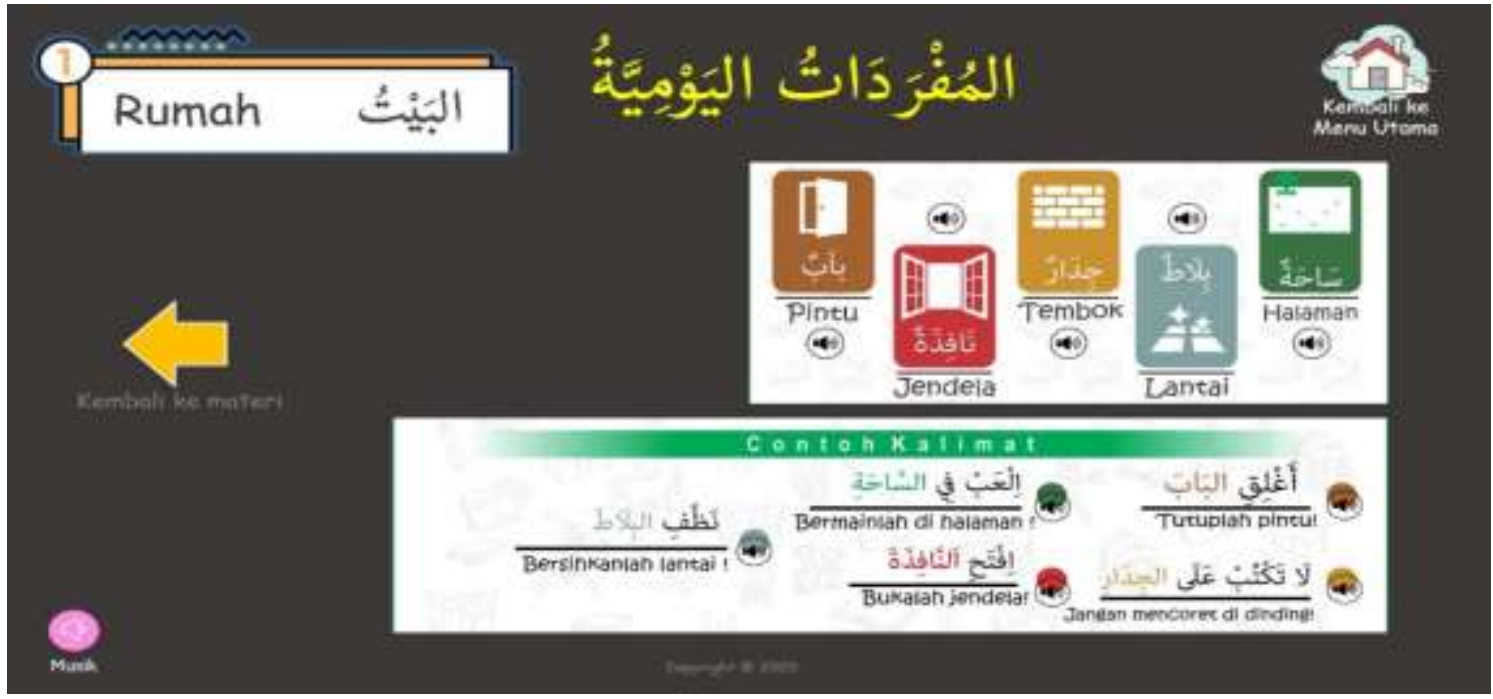

Sumber: Hasil Penelitian (2020)

Gambar 4. Tampilan Materi Kosakata Harian Bahasa Arab di Rumah

Pada tampilan materi "Rumah", selain dapat mengetahui mengenai kosakata harian Bahasa Arab yang terdapat di Rumah, terdapat pula contoh kalimat dan cara mengucapkan dalam Bahasa Arab dengan cara menekan tombol suara. Selain itu terdapat pula menu kembali ke pilihan materi yang dinavigasikan menggunakan tombol "Kembali ke materi", atau tombol "Kembali ke Menu Utama" untuk kembali ke menu utama dan terdapaat pula tombol musik yang dapat didengarkan atau tidak.

Setelah mengetahui materi kosakata harian Bahasa Arab yang terdapat di Rumah beserta contoh kalimat dan cara mengucapkan dalam Bahasa Arab, pengguna dapat memilih tombol "Bilangan" untuk mengetahui materi kedua yang terdapat pada menu materi kosakata harian Bahasa Arab, dapat dilihat pada gambar 5.

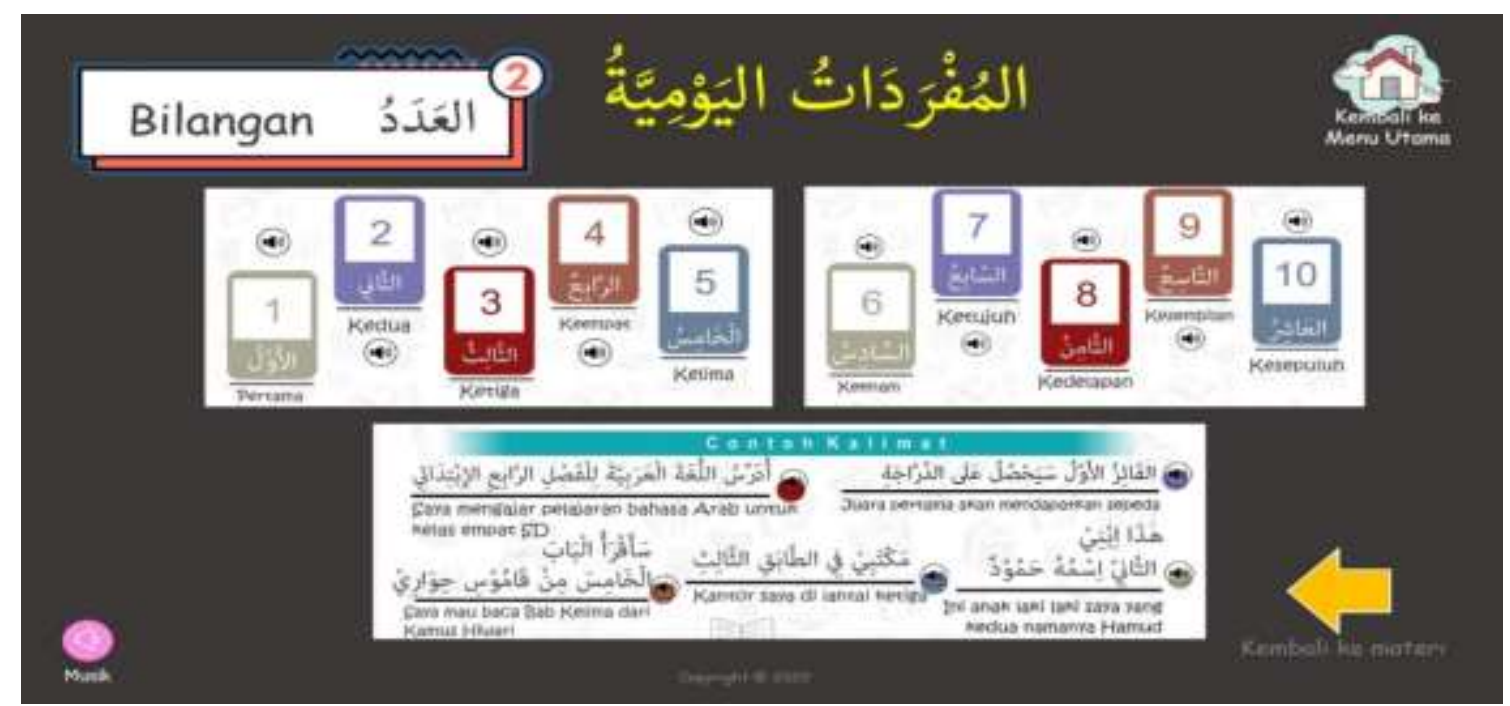

Sumber: Hasil Penelitian (2020)

Gambar 5. Tampilan Materi Kosakata Harian Bilangan 1-10 dalam Bahasa Arab 
Pada tampilan materi "Bilangan", selain dapat mengetahui mengenai beberapa kosakata bilangan dalam Bahasa Arab, terdapat pula contoh kalimat dan cara mengucapkan dalam Bahasa Arab dengan cara menekan tombol suara. Selain itu terdapat pula menu kembali ke pilihan materi yang dinavigasikan menggunakan tombol "Kembali ke materi", atau tombol "Kembali ke Menu Utama" untuk kembali ke menu utama dan terdapaat pula tombol musik yang dapat didengarkan atau tidak. Setelah mengetahui materi mengenai beberapa kosakata bilangan dalam Bahasa Arab beserta contoh kalimat dan cara mengucapkan dalam Bahasa Arab, pengguna dapat memilih tombol "Hewan" untuk mengetahui materi ketiga yang terdapat pada menu materi kosakata harian Bahasa Arab, dapat dilihat pada gambar 6.

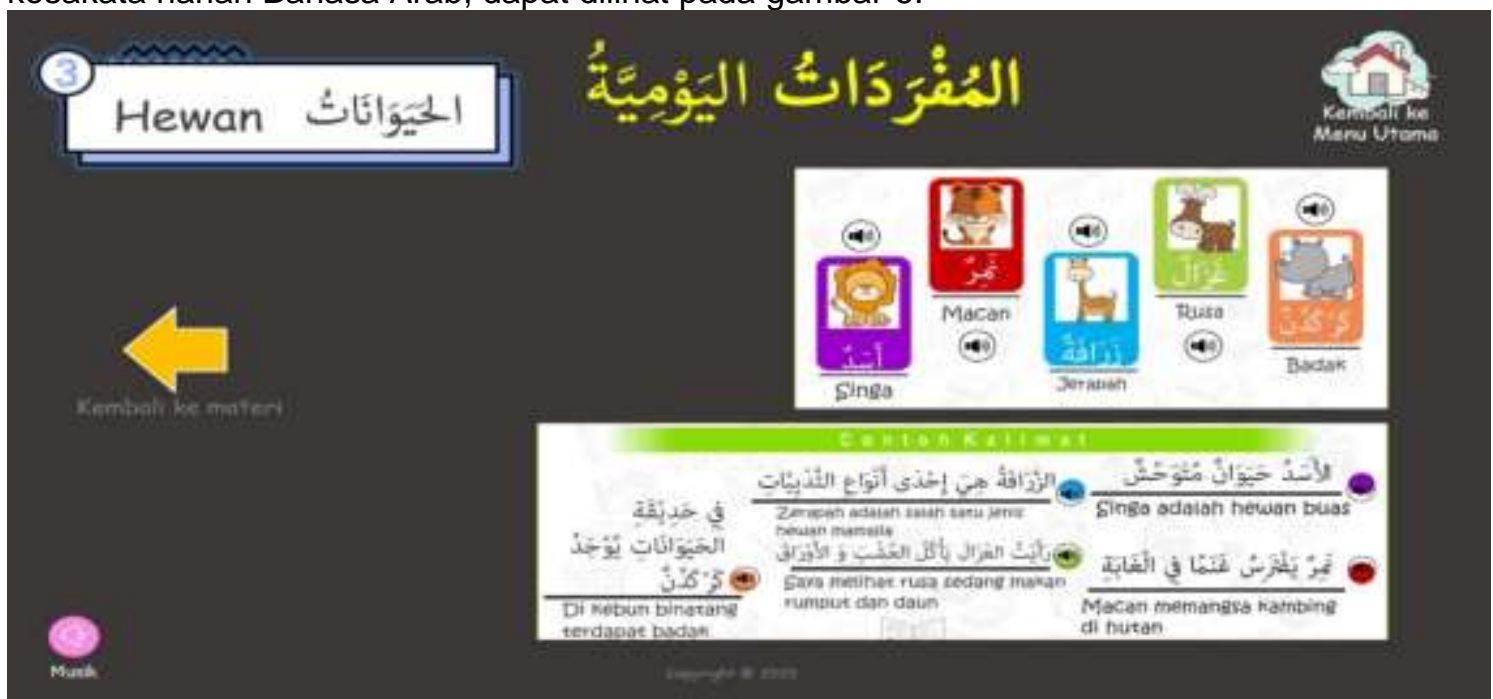

Sumber: Hasil Penelitian (2020)

Gambar 6. Tampilan Materi Kosakata Harian Bahasa Arab beberapa Nama Hewan

Pada tampilan materi "Bilangan", selain dapat mengetahui mengenai beberapa Nama Hewan dalam Bahasa Arab, terdapat pula contoh kalimat dan cara mengucapkan dalam Bahasa Arab dengan cara menekan tombol suara. Selain itu terdapat pula menu kembali ke pilihan materi yang dinavigasikan menggunakan tombol "Kembali ke materi", atau tombol "Kembali ke Menu Utama" untuk kembali ke menu utama dan terdapaat pula tombol musik yang dapat didengarkan atau tidak.

\section{Tampilan Kuis}

Tampilan Kuis muncul ketika pengguna memilih menu "Kuis" yang ada pada menu utama. Pada tampilan utama Kuis terdapat perintah untuk mengisi identitas berupa data nama dan kelas sebelum memulai Kuis. Jika pengguna sudah mengisi data nama dan kelas maka pengguna dapat menekan tombol "Mulai Kuis". Untuk tampilan awal kuis dapat dilihat pada gambar 7.

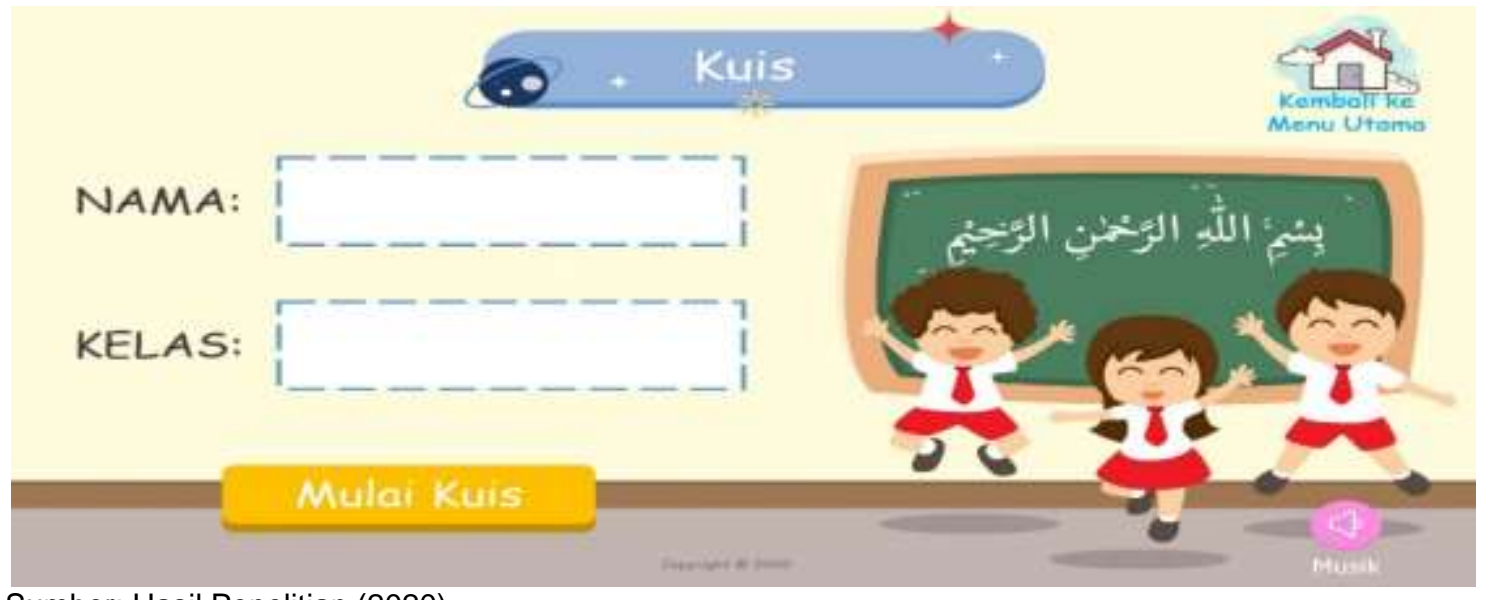

Sumber: Hasil Penelitian (2020)

Gambar 7. Tampilan Utama Quiz 
Pada tampilan utama Kuis, pengguna juga dapat memilih tombol "Kembali ke Menu Utama" untuk kembali ke menu utama serta terdapat pula tombol musik yang dapat didengarkan atau tidak. Tampilan Kuis setelah pengguna menekan tombol mulai adalah berupa memilih jawaban yang benar untuk mengisi titik-titik yang kosong. Pertanyaan sebanyak 5 (lima) pernyataan dan waktu menjawab soal adalah 20 detik per soal. Setiap jawaban yang benar akan mendapatkan poin 20 dan jawaban salah tidak mendapatkan poin. Tampilan Kuis dapat dilihat pada gambar 8.

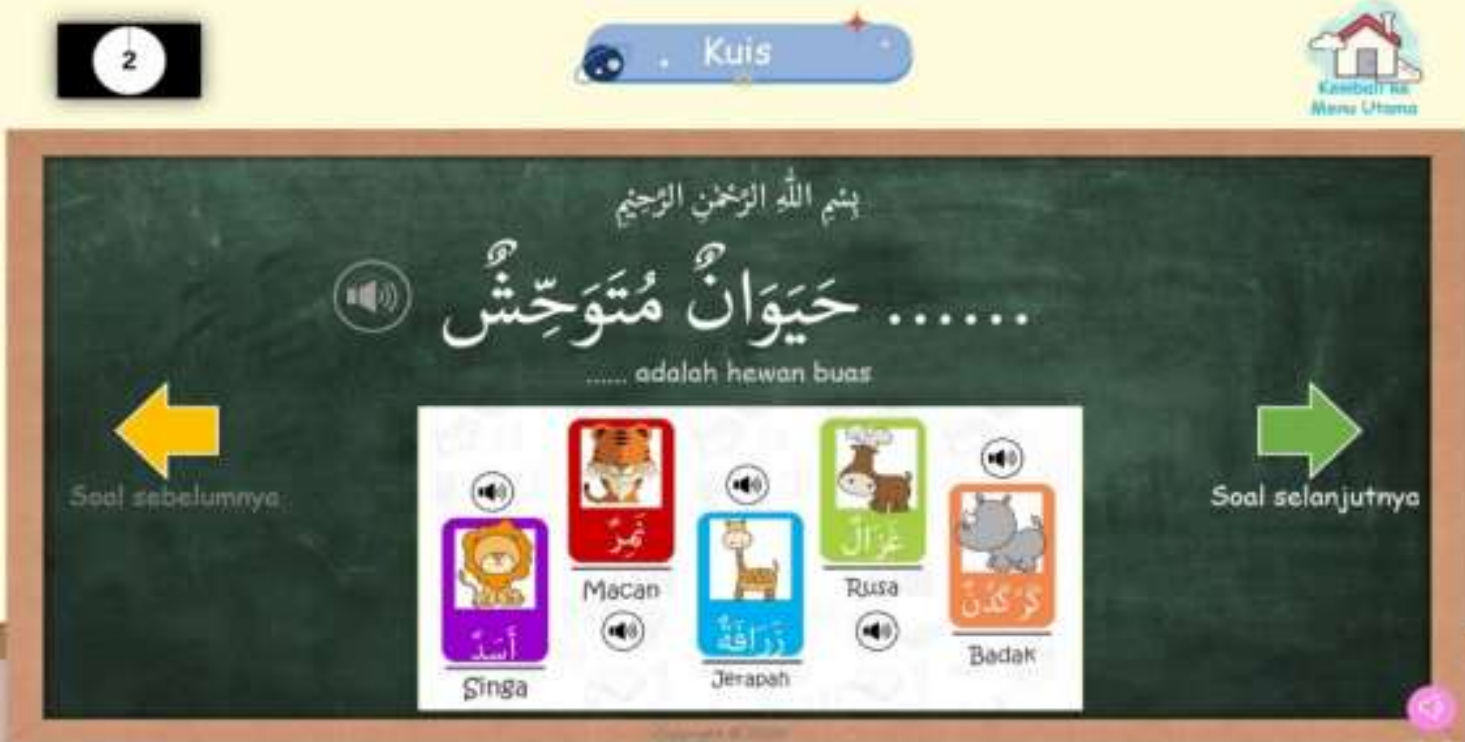

Sumber: Hasil Penelitian (2020)

Gambar 8. Tampilan Pertenyaan Kuis

Pada tampilan Quiz, pengguna juga dapat memilih tombol menu untuk kembali ke menu utama atau memilih soal sebelumnya atau soal selanjutnya. Pengguna dapat melihat hasil jawaban berupa skor akhir dari 5 (lima) pernyataan. Tampilan hasil Kuis dapat dilihat pada gambar 9 .

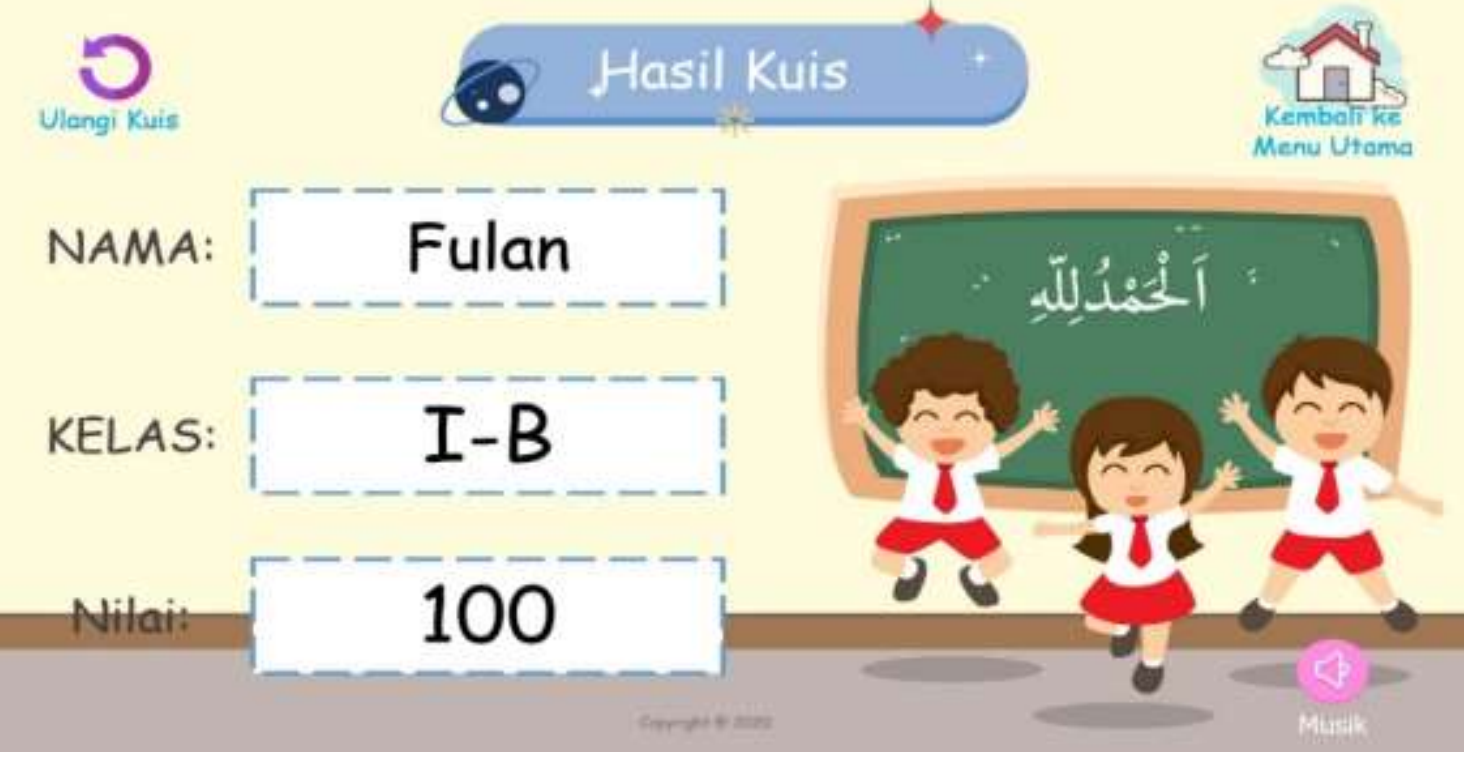

Sumber: Hasil Penelitian (2020)

Gambar 9. Tampilan Hasil Kuis

Pada tampilan skor akhir Kuis, pengguna juga dapat memilih tombol menu untuk kembali ke menu utama atau memilih tombol "Ulangi Kuis" jika pengguna hendak mengulang Kuis dan kembali mengisi identitas data nama dan kelas. 


\section{Tampilan Pengembang}

Selain menu Materi dan menu Kuis, aplikasi media pembelajaran Kosakata Harian Bahasa Arab juga terdapat menu pengembang. Menu pengembang dibuat untuk mengetahui profile pembuat aplikasi. Menu Pengembang dapat dilihat pada gambar 10.

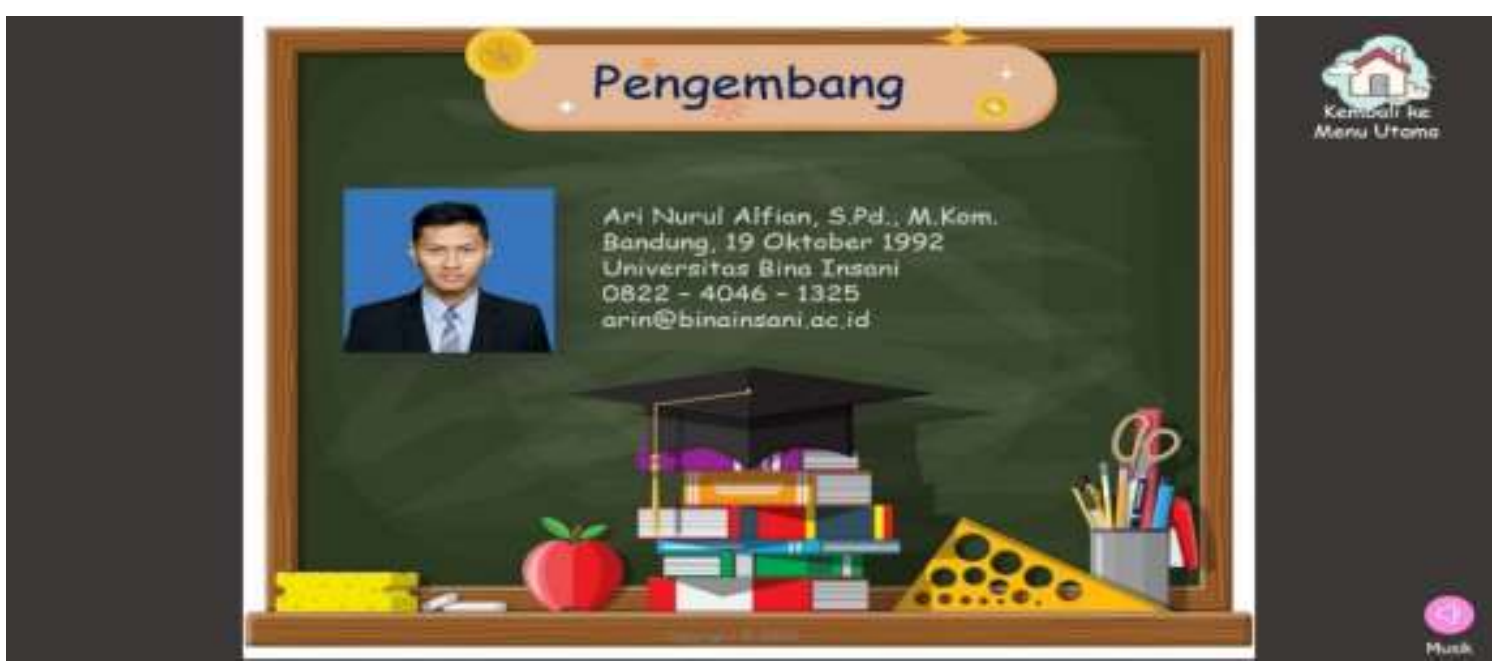

Sumber: Hasil Penelitian (2020)

Gambar 10. Tampilan Profile

Pada tampilan menu pengembang, penguna dapat memilih tombol menu untuk kembali ke menu utama serta tombol musik yang dapat didengarkan atau tidak.

\section{Pengujian dan Analisis Hasil}

Setelah aplikasi media pembelajaran Kosakata Harian Bahasa Arab ini selesai dibuat, dilakukan pula uji coba aplikasi pada perangkat komputer. Jenis pengujian yang dilakukan untuk menguji program aplikasi yang dibuat adalah pengujian black box dan pengujian penerimaan pemakai (user acceptance test / UAT).

Program aplikasi yang dibuat perlu diuji ke beberapa jenis komputer atau laptop dengan merk dan spesifikasi teknis yang berbeda, karena calon pengguna saat menjalankan aplikasi menggunakan laptop atau komputer yang tidak seragam, yaitu Laptop Lenovo G40 dengan Windows 7, komputer prosesor core i3 dengan Windows XP, dan komputer core i3 dengan Windows 7. Hasil pengujian blackbox menunjukkan bahwa program aplikasi berjalan dengan baik pada semua perangkat tersebut.

Pengujian UAT dilakukan secara online dengan mengirimkan file aplikasi yang disimpan pada google formulir untuk kemudian dapat install langsung, sehingga pengguna dapat langsung mengisi kuesioner setelah menggunakan aplikasi media pembelajaran Kosakata Harian Bahasa Arab. Untuk mengetahui aplikasi yang dibuat dapat membantu siswa dalam pembelajaran maka dibuatkan kuesioner. Daftar pertanyaan yang diajukan pada 54 siswa dapat dilihat pada Tabel 1. Hasil prosentase dari tiap pertanyaan pengujian ke siswa ditunjukkan pada Table 3 . Hasil kuesioner tersebut menunjukkan bahwa secara umum program aplikasi sudah memenuhi harapan siswa dan bisa digunakan sebagai media pembelajaran. Poin-poin pertanyaan yang diajukan ke beberapa pengguna yang berprofesi guru sebagai sample user ditunjukkan pada Tabel 3.

Tabel 3 Tabel Pengujian kepada Siswa

\begin{tabular}{|c|c|c|}
\hline No. & Poin-poin yang diteliti & Skala Penilaian \\
\hline 1 & $\begin{array}{l}\text { Apakah Ananda sebelumnya pernah menggunakan aplikasi seperti } \\
\text { ini? }\end{array}$ & \\
\hline 2 & Apakah tampilan aplikasi ini bagus? & $\begin{array}{l}\mathrm{SBg}=61,1 \%, \mathrm{Bg}=38,9 \%, \mathrm{CBg}=0 \% \\
\mathrm{~J}=0 \%, \mathrm{SJ}=0 \%\end{array}$ \\
\hline 3 & $\begin{array}{l}\text { Apakah pengoperasian aplikasi Media Pembelajaran Kosakata } \\
\text { Harian Bahasa Arab pada aplikasi ini mudah? }\end{array}$ & $\begin{array}{l}\mathrm{SM}=66,7 \%, \mathrm{M}=27,8 \%, \mathrm{CM}=5,6 \% \\
\mathrm{TM}=0 \%, \mathrm{STM}=0 \%\end{array}$ \\
\hline 4 & Apakah proses menjalankan aplikasi ini cepat? & $\begin{array}{l}S C p=48,1 \%, C p=42,6 \%, C C p= \\
9,3 \%, L=0 \%, S L=0 \%\end{array}$ \\
\hline 5 & $\begin{array}{l}\text { Apakah fitur aplikasi Media Pembelajaran Kosakata Harian Bahasa } \\
\text { Arab ini bermanfaat? }\end{array}$ & $\begin{array}{l}\mathrm{SBm}=87 \%, \mathrm{Bm}=13 \%, \mathrm{CBm}=0 \% \\
\mathrm{TBm}=0 \%, \mathrm{STBm}=0 \%\end{array}$ \\
\hline
\end{tabular}




\begin{tabular}{|c|c|c|}
\hline No. & Poin-poin yang diteliti & Skala Penilaian \\
\hline 6 & $\begin{array}{l}\text { Apakah tingkat error aplikasi Media Pembelajaran Kosakata Harian } \\
\text { Bahasa Arab ini tingai? }\end{array}$ & $\mathrm{SR}=33,3 \%, \mathrm{R}=44,4 \%, \mathrm{CT}=14,8 \%$, \\
\hline & Apakah keseluruhan aplikasi Media Pembelajaran Kosakata Harian & $\mathrm{SBg}=61,1 \%, \mathrm{Bg}=35,2 \%, \mathrm{CBg}=$ \\
\hline 7 & Bahasa Arab ini bagus? & $3,7 \%, \mathrm{~J}=0 \%, \mathrm{SJ}=0 \%$ \\
\hline 8 & Apakah aplikasi ini cocok untuk media belajar mandiri/tanpa guru? & $\begin{array}{l}\mathrm{SC}=59,3 \%, \mathrm{C}=31,5 \%, \mathrm{CC}=7,4 \%, \\
\mathrm{TC}=3,7 \%, \mathrm{STC}=0 \%\end{array}$ \\
\hline
\end{tabular}

Sumber: Penelitian (2020)

Tabel 4 menunjukkan hasil prosentase dari tiap pertanyaan pengujian ke 16 guru. Hasil pengujian menunjukkan bahwa secara umum program aplikasi sudah layak untuk digunakan sebagai media pembelajaran di sekolah.

Tabel 4 Tabel Pengujian kepada Guru

\begin{tabular}{|c|c|c|}
\hline No. & Poin-poin yang diteliti & Skala Penilaian \\
\hline 1 & $\begin{array}{l}\text { Apakah Bapak/lbu Guru sebelumnya pernah menggunakan aplikasi } \\
\text { seperti ini? }\end{array}$ & $S=25 \%, B=75 \%$ \\
\hline 2 & Apakah tampilan aplikasi ini bagus? & $\begin{array}{l}\mathrm{SBg}=50 \%, \mathrm{Bg}=50 \%, \mathrm{CBg}=0 \%, \mathrm{TBg}= \\
0 \%, \mathrm{STBg}=0 \%\end{array}$ \\
\hline 3 & Apakah pengoperasian aplikasi ini mudah? & $\begin{array}{l}\mathrm{SM}=75 \%, \mathrm{M}=25 \%, \mathrm{CM}=0 \%, \mathrm{TM}= \\
0 \%, \mathrm{STM}=0 \% .\end{array}$ \\
\hline 4 & Apakah kecepatan loading aplikasi ini cepat? & $\begin{array}{l}\text { SCp }=43,8 \%, C p=50 \%, C C p=6,3 \% \\
\text { TCp }=0 \%, \text { STCp }=0 \%\end{array}$ \\
\hline 5 & $\begin{array}{l}\text { Apakah fitur Media Pembelajaran Kosakata Harian Bahasa Arab ini } \\
\text { bermanfaat? }\end{array}$ & $\begin{array}{l}\mathrm{SBm}=93,8 \%, \mathrm{Bm}=6,3 \%, \mathrm{CBm}=0 \% \\
\mathrm{TBm}=0 \%, \mathrm{STBm}=0 \%\end{array}$ \\
\hline 6 & $\begin{array}{l}\text { Apakah soal-soal kuis sudah mencakup evaluasi keseluruhan } \\
\text { program? }\end{array}$ & $\begin{array}{l}\mathrm{SM}=43,8 \%, \mathrm{M}=50 \%, \mathrm{CM}=6,3 \%, \mathrm{TM}= \\
0 \%, \mathrm{STM}=0 \%\end{array}$ \\
\hline 7 & $\begin{array}{l}\text { Apakah aplikasi Media Pembelajaran Kosakata Harian Bahasa } \\
\text { Arab ini sudah lengkap? }\end{array}$ & $\begin{array}{l}\text { SLk }=50 \%, \text { Lk }=37,5 \%, \text { CLk }=12,5 \% \\
\text { TLk }=0 \%, \text { STLk }=0 \%\end{array}$ \\
\hline 8 & Apakah aplikasi ini cocok untuk media belajar mandiri/tanpa guru? & $\begin{array}{l}\mathrm{SC}=62,5 \%, \mathrm{C}=18,8 \%, \mathrm{CC}=18,8 \% \\
\mathrm{TC}=0 \%, \mathrm{STC}=0 \%\end{array}$ \\
\hline 9 & $\begin{array}{l}\text { Apakah Media Pembelajaran Kosakata Harian Bahasa Arab ini } \\
\text { membantu dalam proses belajar mengajar? }\end{array}$ & $\begin{array}{l}\mathrm{SMb}=100 \%, \mathrm{Mb}=0 \%, \mathrm{CMb}=0 \% \\
\mathrm{TM}=0 \%, \mathrm{STM}=0 \%\end{array}$ \\
\hline
\end{tabular}

Sumber: Penelitian (2020)

\section{Kesimpulan}

Kesimpulan dari hasil pengujian program aplikasi yang sudah dibuat dengan Adobe Flash Professional CS6 berjalan baik pada laptop dengan sistem operasi Windows XP dan Windows 7. Setelah program aplikasi dijalankan seperti menu utama, menu materi, menu kuis, dan menu pengembang fitur-fitur berjalan dengan baik. Hasil survey dan kuisioner materi yang terdapat pada program aplikasi sesuai dengan materi yang dibutuhkan. Program aplikasi media pembelajaran Kosakata Harian Bahasa Arab ini cocok untuk media belajar mandiri siswa.

\section{Referensi}

[1] R. Ahmadi, Pengantar Pendidikan. Yogyakarta: Ar-Ruzz Media, 2015.

[2] A. Arsyad, Bahasa Arab Dan Metode Pengajarannya. Yogyakarta: Pustaka Pelajar, 2004.

[3] E. Mulyasa, Kurikulum Berbasis Kompetensi. Bandung: Remaja Rosdakarya, 2004.

[4] M. Al-Ghulayani, Jami'u Ad-Durusu Al-Arabiyah. Beirut: Maida, 1987.

[5] S. Mustofa, Strategi Pembelajaraan Bahasa Arab Inovatif. Malang, 2011.

[6] A. Hamd, Mengukur Kemampuan Bahasa Arab. Malang, 2013.

[7] D. Indriana, Ragam Alat Bantu Media Pengajaran. Yogyakarta: Diva Press, 2011.

[8] M. I. Hanafri, S. Ramdhan, and K. Nisa, "Aplikasi Pembelajaran Interaktif Pengenalan Profesi Berbasis Multimedia Menggunakan Adobe Flash CS6," J. Sisfotek Glob., vol. 7, no. 2, pp. 38-44, 2017.

[9] Wandah, Desain dan Pemrograman Multimedia Interaktif. Jember: Cerdas Ulet Kreatif, 2017.

[10] I. dan F. D. Wijaya, "Jurnal Pendidikan Teknologi Informasi," J. Pendidik. Teknol. Inf., vol. 5, no. 2, pp. 9-20, 2018.

[11] A. S. Sadiman, Media Pendidikan. Jakarta: CV Rajawali, 1986.

[12] I. Mustholiq, Sukir \& Ariade Chandra, "Pembelajaran Interaktif Berbasis Multimedia Mata Kuliah Dasar Listrik. Jurnal Penelitian dan Teknologi Kejuruan,” vol. 16, no. 1, p. 7, 2007.

[13] Madcoms, Kupas Tuntas Adobe Flash CS6. Yogyakarta: CV Andi Offset, 2016. 